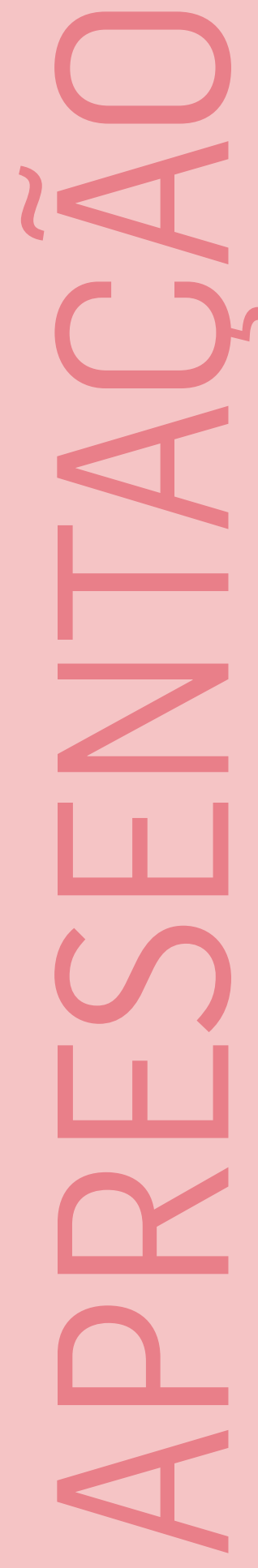

\title{
Até onde a informação pode cegar?
}

\section{At what point does information make you blind? \\ ¿Hasta qué punto puede cegar la información?}

0 mundo dá voltas, já diz o dito popular; algo que a ciência, há muito, já comprovou. Essa conjunção entre a crença popular e a pesquisa nem sempre acontece, por mais absurdo que pareça. Alguns autores já destacam há tempos o crescimento da sabedoria das multidões, ou a predisposição a crer naquilo que se deseja, mesmo sem nenhum fundamento ou comprovação. E isso, esse olhar sofômano, pode ser alimentado até mesmo pela informação - ou pela seleção das informações que melhor confirmem o olhar enviesado de ocasião.

Envoltos em uma das maiores crises de todos os tempos, com perdas inestimáveis de vidas em todos os lugares - dos mais ricos aos mais pobres -, muitos países se debatem contra a desinformação, contra as chamadas fake news, contra as distorções tanto acidentais quanto intencionais de informação. 0 deslocamento da verdade move opiniões como se parte do mundo estivesse em um estádio de futebol amplo e de reverberação de situações-limite, alimentando-se de paixões.

A Organicom reúne artigos, neste número dossiê com o tema "Opinião pública e comunicação", a fim de debater as construções que têm feito momentos de gravidade extrema não serem entendidos por causa de movimentos populistas que retiram o olhar sobre o fato e distorcem a realidade. 0 crescimento de ações voltadas à geração de negacionismos e extremismos marca países na Europa e nas Américas, não deixando de fora o Brasil em que, mesmo diante de uma crise de saúde pública, as opiniões se movem alheias à realidade.

Neste número, pudemos conversar com o filósofo Pablo Ortellado, professor da Universidade de São Paulo, sobre os movimentos que buscam controlar as fake news, possível legislação reguladora e o comportamento das plataformas de redes sociais digitais na gestão desse tema. 
O Espaço Aberto - editoria voltada a temas essenciais, mas que não estejam contemplados no dossiê - traz 0 artigo "Comunicação pública e campanhas de amamentação: representações da mulher-mãe", vencedor do Prêmio Abrapcorp de Teses e Dissertações na categoria Mestrado, elaborado por Amanda Braga Silveira e Rudimar Baldissera. Traz também 0 artigo "Comunicação em ouvidoria: um caso de prática organizacional", produzido pelos pesquisadores Flávia Almeida Moura, Pedro Germano Nobre Neto e Bruna Rafaela Almeida da Costa.

0 dossiê abre com o texto da professora Elizabeth Saad intitulado "A comunicação das organizações diante de públicos, esfera pública e opinião pública: como as plataformas sociais digitais se encaixam nisso?". Além desse, os autores Ricardo Germano Tesseroli e Pedro Chapaval Pimentel oferecem à leitura o artigo "No que você está pensando? Apontamentos sobre opinião pública nas redes sociais digitais", seguido de "O conceito de opinião pública na teoria da comunicação: genealogias e modos de abordagem", redigido pelos pesquisadores Luis Mauro Sá Martino e Angela Cristina Salgueiro Marques. Fechando o dossiê, o professor Gustavo Eugênio Hasse Becker apresenta o artigo "A opinião pública na produção literária e acadêmica de relações públicas no Brasil: 1960-2019".

A Organicom traz, ainda, duas resenhas de obras que podem contribuir para a reflexão em tempos de colapso da opinião: a obra Opinião pública, comunicação e organizações: convergências e perspectivas contemporâneas - organizada pelos pesquisadores Luiz Alberto de Farias, Else Lemos e Claudia Rebechi a partir de congresso com mesmo tema organizado pela Associação Brasileira de Pesquisadores em Comunicação Organizacional e Relações Públicas (Abrapcorp) - é resenhada pela professora Ágatha Camargo Paraventi com o título "Opiniões sem discussões públicas". Também temos a resenha sobre 0 livro Do fascismo ao populismo na história, do historiador Federico Finchelstein, produzida pela professora Vânia Penafieri sob o título "Roda mundo, roda gigante", destacando a obra que discute a evolução dos dois conceitos presentes no livro.

Esperamos que esta edição aprofunde o debate sobre opinião pública e desinformação, contribuindo para o fortalecimento das instituições e da Ciência.

Boa leitura!

Coordernadores do dossiê

LUIZ ALBERTO DE FARIAS

VALÉRIA CASTRO

DANIEL REIS DA SILVA 